\title{
O NEKIM POSEBNIM SLUČAJEVIMA SEPARATNOG ODLUČIVANJA O NAKNADI PARNIČNIH TROŠKOVA
}

Prof. emer. dr. sc. Mihajlo Dika*

\author{
UDK 347.951 \\ https://doi.org/10.30925/zpfsr.42.2.1 \\ Ur.: 22. ožujka 2021. \\ Pr.: 18. travnja 2021. \\ Izvorni znanstveni rad
}

\begin{abstract}
Sažetak
U radu se obrađuje šest procesnih situacija u kojima je posebnim odredbama Zakona o parničnom postupku uređena mogućnost traženja separatne naknade troškova uzrokovanih jednoj od stranaka tijekom postupka radnjama protivne stranke koje se mogu pripisati njenoj krivnji ili slučaju koji joj se dogodio. Riječje o naknadi troškova uzrokovanih postavljanjem (nedopuštenog ili) neosnovanog zahtjeva za izuzeće suca, podnošenjem prijedloga za povrat u prijašnje stanje, ometanjem dostave i njenim neurednim obavljanjem, nepravodobnim iznošenjem novih činjenica i predlaganjem novih dokaza te nepravodobnim podnošenjem podnesaka. Analizom navedenih instituta i nastoji se odrediti njihov sadržaj de lege lata te predložiti korekcije njihova uređenja de lega ferenda.
\end{abstract}

Ključne riječi: troškovi postupka; izuzeće suca; povrat u prijašnje stanje; dostava; nove činjenice i dokazi.

\section{UVOD}

Osnovno polazno načelo hrvatskoga parničnog troškovnog materijalnog prava mjerodavno za konačno snošenje troškova postupka, za donošenje odluke o tome koja će od stranaka biti dužna protivnoj stranci i njezinu umješaču naknaditi troškove postupka - jest načelo davanja povoda za vođenje postupka. To znači da će troškove postupka u načelu konačno snositi ona stranka koja je dala povod za njegovo vođenje, ako posebnim postupovnim aktivnostima povod za nastanak svih ili samo nekih od njih nije dala protivna stranka ili koji drugi sudionik u postupku.

Opće načelo kojim se izražava to osnovno polazno načelo, načelo koje se primjenjuje ako in concreto nema mjesta primjeni drugih, u osnovi korektivnih, pravila, primjerenih određenim specifičnim situacijama načelo je presumiranog davanja povoda za postupak. Prema njemu se, naime, presumira da je stranka koja je izgubila parnicu dala povod za troškove koji su njenim vođenjem prouzrokovani protivnoj stranci i određenim drugim subjektima toga postupka te ih je tim subjektima

* Dr. sc. Mihajlo Dika, professor emeritus, Pravni fakultet Sveučilišta u Zagrebu; mihajlo.dika@, pravo.hr. ORCID: https://orcid.org/0000-0002-5659-3779. 
i dužna naknaditi. Ona u načelu snosi i vlastite troškove te parnice. Prema tom općem načelu, u slučaju djelomičnoga uspjeha u parnici, dužnost naknade troškova određuje se razmjerno tom uspjehu. (154., ${ }^{1,2} 158 / 1 .{ }^{3}$ i $\left.3 .{ }^{4}\right)$ Navedeno opće načelo korigirano je nizom posebnih načela koja su također inspirirana osnovnim polaznim načelom - načelom davanja povoda za nastanak (u pravilu) svih ili pojedinih troškova u određenom postupku. Riječ je o načelu dokazanog nedavanja $(157 .)^{5}$ i načelu dokazanog davanja povoda za parnicu (158/2.). ${ }^{6}$ Iznimka od osnovnoga polaznog

1 U ovom radu odredbe pojedinih zakona označavat će se navođenjem broja članka, stavka odvojenog kosom crtom od broja članka, te točke ili rečenice u istom stavku, odvojene točkom od broja članka ili stavka. Brojevi više stavaka ili točaka istoga članka ili stavka međusobno će biti razdvojeni zarezom. Crtica između brojeva dvaju članaka ili stavaka koristit će se radi označavanja da se sve odredbe između tih brojeva odnose na tekst ispred njih. Odredbe Zakona o parničnom postupku, Narodne novine, br. 26/91., 53/91., 91/92., 112/99., 88/01., 117/03., 88/05., 2/07., 96/08., 84/08., 123/08., 57/11., 25/13., 70/19. (dalje: ZPP), u zagradama navoditi bez naznake kratice toga zakona.

2 Čl. 154. ZPP-a glasi: „Stranka koja u cijelosti izgubi parnicu dužna je protivnoj stranci i njezinu umješaču naknaditi troškove izazvane vođenjem postupka. Umješač na strani stranke koja je izgubila parnicu dužan je naknaditi troškove koje je uzrokovao svojim radnjama.// Ako su stranke djelomično uspjele u parnici, sud će najprije utvrditi postotak u kojemu je svaka od njih uspjela, zatim će od postotka one stranke koja je u većoj mjeri uspjela oduzeti postotak one stranke koja je u manjoj mjeri uspjela, nakon toga će utvrditi iznos pojedinih i iznos ukupnih troškova stranke koja je u većoj mjeri uspjela u parnici koji su bili potrebni za svrhovito vođenje postupka te će toj stranci odmjeriti naknadu dijela takvih ukupnih troškova koji odgovara postotku koji je preostao nakon navedenog obračuna postotaka u kojima su stranke uspjele u parnici. Omjer uspjeha u parnici ocjenjuje se prema konačno postavljenom tužbenom zahtjevu, vodeći računa i o uspjehu dokazivanja u pogledu osnove zahtjeva.// Neovisno o navedenim pravilima, sud može odrediti da jedna stranka naknadi drugoj stranci pojedine troškove primjenom čl. 156. st. 1. ovoga Zakona.// Ako su stranke djelomično uspjele u parnici u približno jednakim dijelovima, sud može odrediti da svaka stranka snosi svoje troškove ili da jedna stranka naknadi drugoj stranci samo pojedine troškove primjenom čl. 156. st. 1. ovoga Zakona.// Sud može odlučiti da jedna stranka nadoknadi sve troškove koje su protivna stranka i njezin umješač imali ako protivna stranka nije uspjela samo u razmjerno neznatnom dijelu svog zahtjeva, a zbog tog dijela nisu nastali posebni troškovi.// Prema rezultatu dokazivanja sud će odlučiti hoće li troškove iz čl. 153. st. 5. ZPP-a podmirivati jedna ili obje stranke ili će ti troškovi pasti na teret sredstava suda." O odgovornosti za naknadu troškova prema načelu presumiranog davanja povoda za parnicu v. Dika Mihajlo, „O konačnom snošenju parničnih troškova prema načelu presumiranog davanja povoda za parnicu nakon Novele ZPP-a 2019., $\mathrm{u}$ : Novine u parničnom procesnom pravu: okrugli stol održan 6. prosinca 2019. u palači Akademije u Zagrebu, ur. Jakša Barbić (Zagreb: HAZU, 2020.), 17-77.

3 Prema odredbi čl. 158. st. 1. ZPP-a, tužitelj koji povuče tužbu ili se odrekne tužbenog zahtjeva dužan je (u pravilu - arg. ex 158/2.) tuženiku naknaditi troškove postupka.

4 Odredba čl. 158. st. 3. glasi: „Stranka koja odustane od pravnog lijeka dužna je protivnoj stranci nadoknaditi troškove nastale u povodu pravnog lijeka.“

5 Čl. 157. ZPP-a glasi: „Ako tuženik nije dao povod za tužbu i ako je prije nego što se upustio u raspravljanje o glavnoj stvari, priznao tužbeni zahtjev, tužitelj će nadoknaditi tuženiku parnične troškove."

6 Prema odredbi čl. 158. st. 2. ZPP-a, iznimno od odredbe st. 1. toga čl. (v. bilj. 3.), ako je tužitelj povukao tužbu ili se odrekao tužbenog zahtjeva odmah nakon što je tuženik udovoljio zahtjevu tužitelja ili zbog drugih razloga koji se mogu pripisati tuženiku, troškove postupka dužan je tužitelju naknaditi tuženik. 
načela o odgovornosti za troškove prema danom povodu za njihov nastanak jest načelo dokaznoga postojanja opravdanih razloga za davanje povoda za izgubljenu parnicu, koje se tiče samo, tzv. izlučnih parnica (160.). ${ }^{7}$ Iznimka je od osnovnog polaznog načela i pravilo po kojemu svaka stranka snosi svoje troškove ako je parnica završena sudskom nagodbom, a u nagodbi nije drukčije ugovoreno (159/1.).

Osnovno polazno načelo prema kojemu je troškove postupka dužna naknaditi stranka koja je dala povod za njihov nastanak dolazi do izražaja i u slučajevima u kojima se o određenim troškovima posebno odlučuje tijekom postupka - neovisno o tome kako će se riješiti pitanje konačnoga snošenja troškova postupka. Opće pravilo kojim se utvrđuje takva mogućnost separatnog odlučivanja o troškovima postupka jest odredba čl. 156. st. 1. ZPP-a. Prema njoj je stranka dužna, neovisno o ishodu parnice, nadoknaditi protivnoj stranci troškove koje je prouzrokovala svojom krivnjom ili slučajem koji se njoj dogodio. To je pravilo dopunjeno pravilom po kojemu sud može odlučiti da zakonski zastupnik ili punomoćnik stranke nadoknadi protivnoj stranci troškove koje je prouzrokovao svojom krivnjom (156/2.). Riječ je o odredbama kojima je utvrđena posebna odgovornost stranaka i njihovih zastupnika za troškove postupka po načelu (dokazane ili presumirane) krivnje, odnosno takva odgovornost stranaka i po načelu objektivne uzročnosti.

Osim navedenih općih pravila kojima je utvrđena odgovornost stranke i umješača ${ }^{8}$ te njihovih zastupnika po načelu krivnje, odnosno odgovornost stranke i umješača po načelu objektivne uzročnosti, mogućnost takvog separatnog odlučivanja, uz odgovarajuće specifičnosti, predviđena je i za troškove koji mogu biti uzrokovani iniciranjem i vođenjem određenih incidentalnih postupaka. U tom će se ogledu posebna pažnja nastojati posvetiti separatnom odlučivanju po načelima krivnje i objektivne uzročnosti u nekim od tih incidentalnih postupaka. Riječ je postupcima čije je uređenje uvelike izraz nastojanja da se, uz ostalo, i uvođenjem određenih troškovnih sankcija pridonese povećanju opće razine procesne discipline, ekspeditivnosti i ekonomičnosti u parničnom postupku.

\section{OPĆENITO O ODLUČIVANJU O NAKNADI TROŠKOVA POSTUPKA PO NAČELIMA KRIVNJE I OBJEKTIVNE UZROČNOSTI}

Prema već citiranoj odredbi čl. 156. st. 1. ZPP-a, stranka je dužna neovisno o ishodu parnice nadoknaditi protivnoj stranci troškove koje (joj) je uzrokovala

7 Prema odredbi čl. 160. ZPP-a, ako u izlučnoj parnici bude prihvaćen tužbeni zahtjev za proglašenje ovrhe nedopuštenom na određenom predmetu ovrhe, a sud utvrdi da je tuženik kao ovrhovoditelj u ovršnom postupku imao opravdanih razloga smatrati da ne postoje prava trećih osoba na tom predmetu, odredit će da svaka stranka snosi svoje troškove. Mihajlo Dika, „Naknada troškova u izlučnim parnicama“, Pravo u gospodarstvu br. 3 (2020): 405 i slj.

8 O tome da se odredbe čl. 156. ZPP-a na odgovarajući način odnose i na umješača usp. Mihajlo Dika, „O troškovnom statusu umješača nakon Novele Zakona o parničnom postupku iz 2019.“, Zbornik radova $s$ V. međunarodnog savjetovanja „Aktualnosti građanskog procesnog prava nacionalna i usporedna pravnoteorijska i praktična dostignuća", Split, 17. i 18. listopada 2019. godine, ur. Dinka Šago et al. (Split: Sveučilište u Splitu, Pravni fakultet, 2019.), 31-33. 
svojom krivnjom ili slučajem koji se njoj dogodio. S druge strane, prema, također već citiranoj, odredbi st. 2. toga čl. sud može odlučiti i da zakonski zastupnik ili punomoćnik stranke nadoknadi protivnoj stranci troškove koje je uzrokovao svojom krivnjom. ${ }^{9} \mathrm{O}$ zahtjevima za naknadu troškova u navedenim slučajevima sud je dužan, neovisno o odluci o glavnoj stvari, odlučiti najkasnije u roku od 15 dana od dana njihova podnošenja rješenjem (156/3.1.), protiv kojega posebna žalba nije dopuštena i na temelju kojega se ovrha može tražiti prije njegove pravomoćnosti (156/3.2.). ${ }^{10}$

Navedenim odredbama čl. 156. ZPP-a postavljene su, najprije, dvije važne korektivne iznimke od načela presumiranoga davanja povoda za parnicu (154/1., 2.; 158/1,), ${ }^{11}$ ali i od načela dokazanog nedavanja (157.) i dokazanog davanja (158/2.) toga povoda, odnosno od načela dokazanog postojanja opravdanih razloga za oslobođenje od dužnosti naknade troškova po načelu presumiranog davanja povoda za parnicu (160.) (v. supra ad 1.). Jedna od tih korektivnih iznimaka temelji se na načelu krivnje, a druga na načelu objektivne uzročnosti (156/1.). Tim su odredbama, zatim, utvrđene pretpostavke za odgovornost zastupnika stranaka za naknadu troškova postupka po načelu krivnje (156/2.). Njima je, na koncu, uređena i mogućnost promptnog incidentalnog ostvarivanja prava na naknadu troškova za

9 V. bilj. 2. Dika, O konačnom snošenju parničnih troškova prema načelu presumiranog davanja povoda za parnicu nakon Novele ZPP-a 1019.

10 Odredbe čl. 156. st. 1. i 2. ZPP-a imaju svoje normativne uzore, iako u donekle drukčijem sadržaju i značenju, u odredbama $\S \S 150$. i 151. Zakona o sudskom postupku u građanskim parnicama iz 1929. (ZSPGP). Odredbe $\S 150$. ZSPGP-a odgovarale su odredbama $\S 48$. austrijskog Zivilprozeßordnung-a iz 1895. (dalje: öZPO), koje su novelirane 1925. i 1983., a odredbe §151. odredbama §49. öZPO-a, koji je ukinut 1983.

$\S 150$. ZSPGP-a je glasio: „Ako je stranka svojom krivnjom ili slučajem, koji se njoj desio, prouzrokovala protivnoj stranci troškove, onda joj sud može po predlogu ili po službenoj dužnosti naložiti naknadu ovih troškova nezavisno od ishoda parnice.// Stranka, kojoj je naknada takvih troškova već u toku parnice bila dosuđena, nije dužna vratiti ih ni onda, ako bude u glavnoj stvari osuđena na naknadu parničnih troškova“. Novelirana odredba $\S$ 48. st. 1. reč. 1. austrijskoga öZPO-a glasi: „Werden einer Partei dadurch, daß ihr Gegner schuldhaft tatsächliche Anfürungen oder Bewisanbieten verspätet vorbringt, oder lediglich durch Zwischenfälle, die infolge eines Verschulden des Gegners oder eines im wiederfahrenen Zufalles im Laufe des Verfahrens eintreten, Kosten verursacht, so kan ihr das Gericht auf Antrag oder von Amts wegen den Ersatz dieser Kosten unabhängig vom Ausgange des Rechtsstreites zusprechen". O (novoj) odredbi 2. reč. st. 1. § 48. öZPO-a v. bilj. st. 2. § 48. öZPO-a odgovara st. 2. $\S 150$. ZSPGP-a.

$\S$ 151. ZSPGP-a je glasio: „Zakonskim zastupnicima, advokatima i drugim punomoćnicima može sud po predlogu ili po službenoj dužnosti naložiti, da sami snose ili da iz svoje imovine naknade one troškove, koje su prouzrokovali svojom grubom krivnjom.// To naročito vredi i za uvećanje troškova koje je prouzrokovano grubom krivnjom na taj način što se u podnesku navađalo ono što u stvar ne spada ili što su podnesci suviše opširni.// Odluku o tome doneće se zasebnim zaključkom. Pre nego što se odluči, preslušaće se o tome zastupnik, odnosno punomoćnik. Čim ovaj zaključak postane pravosnažnim, može se izvršiti iz imovine dotičnog lica.“

11 U tom je smislu suđeno da sud, iako u pravilu obvezuje na naknadu troškova onu stranku koja je izgubila spor, može iznimno obvezati na naknadu troškova postupka i stranku koja je uspjela u parnici, a koje je ta stranka prouzročila svojom krivnjom ili slučajem koji joj se dogodio. Visoki trgovački sud presuda: Pž-2990/03 od 24.10.2006 - INF-N 5664/06. 
koje se odgovara po ta dva korektivna načela (156/3.), odvojeno od odgovornosti za troškove postupka prema ostalim kriterijima (separacija troškova). ${ }^{12}$

Korektivnost odredaba čl. 156. st. 1. i 2. ZPP-a očituje se u tome što se pri odlučivanju o naknadi troškova prema tim odredbama, za razliku od odlučivanja po pravilima o naknadi troškova (u pravilu cjelokupnoga) postupka (154.; 158/1., 3.; 158/2.; 157.; 160.; v. supra ad 1.), polazi od načela dokazanog ili presumiranog davanja povoda za nastanak posebnih troškova, troškova koji su uzrokovani pojedinim aktivnim radnjama ili propuštanjima sudionika u postupku, odnosno nekim drugim okolnostima koje su nastale tijekom postupka. Upravo je stoga propisano da se o naknadi tih posebnih troškova odlučuje odvojeno i neovisno o odlučivanju o konačnom snošenju troškova postupka. Na naknadu troškova po načelima krivnje i objektivne uzročnosti stranka ima pravo neovisno o tome hoće li ili neće imati pravo na naknadu troškova po kojem od kriterija za odlučivanje o konačnom snošenju troškova postupka. Stoga se o zahtjevima za naknadu troškova iz čl. 156. st. 1. (i 2.) ZPP-a odlučuje bez odgode, neovisno o odluci o glavnoj stvari (156/3.). ${ }^{13}$ Upravo se stoga, čak i kada se o naknadi određenih troškova primjenom odredbe čl. 156. st. 1. ZPP-a (iznimno) odlučuje u istoj odluci, u kojom se odlučuje i o konačnom snošenju troškova postupka, moraju odvojeno utvrditi troškovi o čijoj se naknadi odlučuje primjenom te odredbe i kao takvi posebno uzeti u obzir prigodom određivanja ukupne mase troškova koje bi jedna od stranaka bila dužna naknaditi drugoj.

Korektivno značenje odredaba čl. 156. ZPP-a posebno je naglašeno u odredbama čl. 154. st. 3. i 4. ZPP-a. ${ }^{14} \mathrm{U}$ st. 1. i 2. utvrđena su pravila o konačnom snošenju troškova postupka po načelu presumiranog davanja povoda za parnicu. U st. 1. utvrđena su pravila o takvom snošenju prema tom načelu u slučaju u kojemu je jedna od stranka u cijelosti izgubila parnicu. U stavku 2. utvrđena su pravila o takvom snošenju prema tom načelu u slučaju u kojemu su stranke djelomično uspjele u parnici. ${ }^{15}$ Prema odredbi čl. 154. st. 3. ZPP-a, neovisno o pravilima iz stavka 1. i 2. čl. 154. ZPP-a, sud može odrediti da jedna stranka naknadi drugoj stranci pojedine troškove primjenom

12 U austrijskoj doktrini (usp., npr. Walter H. Rechberger, Daphne-Ariane Simotta, Grungriss des österreichischen Zivilprozessrechts, Erkenntnisverfahren (Wien: Manz Verlag, 2017.), 265) izraz separacija troškova (Kostenseparation) koristi se za označavanje slučajeva u kojima je sud ovlašten o pojedinim troškovima postupka odlučiti odvojeno i neovisno o odluci kojom odlučuje o konačnom snošenju troškova nekoga postupka. Betetto ističe da je za odlučivanje o naknadi troškova po načelu krivnje određujuće da su odvojeni od svih drugih troškova i da se o njima odlučuje odvojeno, zbog čega se i nazivaju separatnim troškovima. Nina Betetto, u: Pravdni postopek: Zakon s komentarjem, 2. knjiga, ur. Lojze Ude et al. (Ljubljana: Uradni list Republike Slovenije: GV založba, 2006.), 43.

$13 \mathrm{Ta}$ je odvojenost prava na naknadu troškova po načelima krivnje i objektivne uzročnosti posebno bila naglašena odredbom st. 2 . § 150. ZSPGP-a. Ona je naglašena i odredbom $\S 48$. st. 2. öZPO (v. bilj. 8.) (v. i Michael Bydlinski, u: Kommentar zu den Zivilprozessgesetzen 2. Band / 1. Teilband EGZPO, $\S \S 1$ bis 73 ZPO, Hans Walter Fasching, Andreas Konecny (Wien: Manz, 2002.), 701.

14 V. bilj. 2. Dika, O konačnom snošenju parničnih troškova prema načelu presumiranog davanja povoda za parnicu nakon Novele ZPP-a 2019.

15 V. bilj. 2. Dika, O konačnom snošenju parničnih troškova prema načelu presumiranog davanja povoda za parnicu nakon Novele ZPP-a 2019. 
odredaba čl. 156. st. 1. ZPP-a. Prema odredbi st. 4. čl. 154. ZPP-a, ako su stranke djelomično uspjele u parnici u približno jednakim dijelovima, sud može odrediti da svaka stranka snosi svoje troškove ili da jedna stranka naknadi drugoj stranci pojedine troškove primjenom čl. 156. st. 1. ZPP-a. ${ }^{16}$

\section{SEPARATNO ODLUC̆IVANJE O NAKNADI TROŠKOVA UZROKOVANIH POSTAVLJANJEM (NEDOPUŠTENOG ODNOSNO) NEOSNOVANOG ZAHTJEVA ZA IZUZEĆE}

Prema odredbi čl. 76. st. 6. ZPP-a, sud je dužan, na zahtjev protivne stranke, bez odgode odlučiti o naknadi troškova postupka koji su toj stranci uzrokovani postavljanjem neutemeljenoga zahtjeva za izuzeće, i to rješenjem protiv kojega posebna žalba nije dopuštena i na temelju kojega se ovrha može tražiti i prije njegove pravomoćnosti. Iako se u navedenoj odredbi govori samo o neosnovanom zahtjevu za izuzeće, stranka bi prema toj odredbi, a fortiori, trebala moći tražiti naknadu troškova i ako bi zahtjev protivne stranke za izuzeće (kao formalni akt) bio odbačen kao nedopušten (arg. ex 73.). ${ }^{17}$

Za odlučivanje o zahtjevu za naknadu troškova uzrokovanih postavljanjem (nedopuštenog i/ili) neosnovanog zahtjeva za izuzeće bilo bi dovoljno, doslovno po Zakonu, utvrditi objektivnu okolnost (nedopuštenosti i/ili) neosnovanosti toga zahtjeva - na temelju nepravomoćne odluke o (odbacivanju i/ili) odbijanju zahtjeva. Naime, protiv rješenja kojim se zahtjev za izuzeće odbacuje ili odbija nije dopuštena posebna žalba (73/4.), zbog čega je ono odmah „ovršno“ (378/2.). To treba shvatiti i u smislu da ono proizvodi i svoje druge učinke prije pravomoćnosti, uz ostalo, i prejudcijelni (12/1.).

Polazeći od navedenog tumačenja odredbe čl. 75. st. 6. ZPP-a, valja zaključiti da je njome glede prava na traženje naknade troškova u slučaju na koji se odnosi prihvaćeno načelo presumirane objektivne uzročnosti: da bi jedna od stranaka mogla tražiti naknadu troškova prema toj odredbi, bilo bi dovoljno da zahtjev za izuzeće protivne stranke budu (odbačen ili) odbijen; uz odluku (o odbacivanju ili) odbijanju zahtjeva za izuzeće kao presumptivnu bazu vezao bi se presumptivni zaključak da

16 Odredbama st. 3. i 4. čl. 154. ZPP-a utvrđena je, premda se u njima koristi sintagma „sud može“ (v. bilj. 2.), dužnost suda da odluči o naknadi pojedinih troškova primjenom odredbe čl. 156. st. 1. ZPP-a odvojeno od odluke o konačnom snošenju troškova postupka (separacija troškova). Na takav zaključak upućuje odredba st. 3. čl. 156. ZPP-a prema kojoj je sud dužan donijeti posebnu odluku o naknadi troškova kad su za to ispunjene pretpostavke iz čl. 156. st. 1. i 2. ZPP-a. Na takav zaključak upućuje i odredba čl. 75. st. 6. ZPP-a o odlučivanju o naknadi troškova postupka izazvanih podnošenjem nedopuštenog zahtjeva za izuzeće (v. infra ad 3.), ali i odredba čl. 122.a reč. 2. ZPP-a o naknadi troškova u povodu povrata u prijašnje stanje (v. infra ad 4.).

17 Stranke mogu tražiti izuzeće samo suca koji sudjeluje u određenom postupku, odnosno predsjednika suda koji o zahtjevu za izuzeće treba odlučiti (73/1.). Pritom nije dopušten zahtjev za izuzeće: (1.) kojim se uopćeno traži izuzeće svih sudaca nekoga suda ili svih sudaca koji bi mogli suditi u nekom predmetu, (2.) o kojem je već odlučeno i (3.) u kojem nije naveden obrazloženi razlog zbog kojega se traži izuzeće (73/2.). 
je podnositelj zahtjeva dao povod za nastanak troškova koji bi njime bili izazvani. Razlozi pravičnosti, pojačani dužnošću savjesnoga korištenja pravima u postupku (9.) i zabranom zloupotrebe prava u postupku (10/1.), zahtijevali bi, međutim, da se odgovornost stranke koja je postavila (nedopušteni odnosno) neosnovani zahtjev za izuzeće isključi u onim slučajevima u kojima bi povod za njegovo postavljanje dala protivna stranka - skrivljeno ili slučajem koji joj se dogodio (156.). Na takav bi pristup, per analogiam, upućivala i odredba prema kojoj se predmnijeva da je povod za parnicu i time za nastanak troškova koji su u njoj uzrokovani protivnoj stranci (tuženiku) dala stranka (tužitelj) koja ju je izgubila (154. ${ }^{18}$ može oboriti dokazivanjem da je povod za parnicu ipak dala protivna stranka (tuženik) $(158 / 2.) .{ }^{19}$

I pri odmjeravanju troškova o kojima je riječ uzimali bi se u obzir samo oni od troškova čija je naknada bila zatražena za koje sud ocijeni da su bili potrebni za ostvarivanja pravozaštitnog rezultata koji je stranka koja traži njihovu naknadu nastojala postići u incidentalnom postupku iniciranom nedopuštenim, odnosno neosnovanim zahtjevom za izuzeće protivne stranke (arg. ex 155.), dakle odbacivanje odnosno odbijanje toga zahtjeva.

Neovisno o gore rečenom, moglo bi se, već de lege lata, postaviti pitanje opravdanosti navedenoga doslovnog tumačenja odredbe čl. 75. st. 6. ZPP-a prema kojemu je za osudu na naknadu troškova postupka dovoljno utvrditi objektivnu okolnost (nedopuštenosti odnosno) neosnovanosti zahtjeva za izuzeće. Pitanje koje se $\mathrm{u}$ vezi s takvim tumačenjem postavlja jest ograničava li se njime neproporcionalno ${ }^{20}$ pravo stranke da inzistira na tome da joj sudi nepristrani sud ${ }^{21}$ ako bi imala opravdanih razloga posumnjati da postoji koji od razloga za izuzeće. Stranka, naime, ne bi smjela radi ostvarivanja svojih Ustavom zajamčenih prava, onda kada za to postoje opravdani razlozi, biti obeshrabrena rizikom da će biti osuđena da protivnoj stranci naknadi troškove uzrokovane postavljanjem zahtjeva za izuzeće, čak i ako uspije u glavnom sporu. De lege ferenda (ako se već de lege lata, kreativnim iskorakom sudske prakse, radi usklađivanja odredbe o kojoj je riječ s Ustavom ne bi razvilo takvo njeno tumačenje), valjalo bi razmisliti i o mogućoj zamjeni važećega kriterija za odlučivanje o zahtjevu za naknadu troškova uzrokovanih nedopuštenim odnosno neosnovanim zahtjevom za izuzeće, kriterijem opravdanog razloga, eventualno u okviru šireg prihvaćanja toga kriterija kao kriterija za odlučivanje o pravu na naknadu troškova postupka, kriterija koji je prema važećem uređenju mjerodavan samo u izlučnim parnicama (160.). ${ }^{22} \mathrm{U}$ tom bi slučaju svaka stranka snosila svoje troškove

18 V. bilj. 2. Dika, O konačnom snošenju parničnih troškova prema načelu presumiranog davanja povoda za parnicu nakon Novele ZPP-a 2019.

19 V. bilj. 6.

20 Prema odredbama čl. 16. Ustava Republike Hrvatske, Narodne novine, br. 56/90., 135/97., 8/98., 113/02., 124/00., 28/01., 41/01., 55/01., 76/10., 85/10. (dalje: URH), slobode i prava mogu se ograničiti samo zakonom da bi se zaštitila sloboda i prava drugih ljudi te pravni poredak, javni moral i zdravlje (st. 1.), s time da svako ograničenje slobode i prava mora biti razmjerno naravi potrebe za ograničenjem u svakom slučaju (st. 2.).

21 Prema odredbi čl. 29. st. 1. URH-a, svatko ima pravo da zakonom ustanovljeni neovisni i nepristrani sud pravično i u razumnom roku odluči o njegovim pravima i obvezama.

22 Prihvaćanje standarda opravdanih razloga imalo bi i svojih „,negativnih strana” utoliko što bi se njime „omekšala” relativna „tvrdoća” važećeg rješenja čiji ratio. S jedne strane, treba tražiti u 
incidentalnog postupka pokrenutog nedopuštenim, odnosno neosnovanim zahtjevom za izuzeće.

U troškove čiju naknadu stranka ima pravo tražiti prema odredbi čl. 75. st. 6 . ZPP-a pripadali bi, svakako, i dodatni troškovi koji bi u ,glavnom postupku“ bili izazvani postavljenjem (nedopuštenog odnosno) neosnovanog zahtjeva za izuzeće, npr. troškovi ročišta u tom postupku koje bi bilo odgođeno zato što je na njemu bio postavljen taj zahtjev. Tu bi pripadali i troškovi incidentalnog postupka koji bi tim zahtjevom bio iniciran, npr. troškovi sastavljanja podneska kojim bi se protivna stranka očitovala o njemu ili troškovi posebnog ročišta koje bi bilo određeno u povodu njega. U te bi troškove trebalo svrstati i troškove međupostupka koji bi bio pokrenut zahtjevom za naknadu troškova prema odredbi čl. 75. st. 6. ZPP-a.

Ono što je rečeno o dužnosti stranke da naknadi troškove koji su protivnoj stranci uzrokovani neosnovanim odnosno nedopuštenim zahtjevom za izuzeće, odnosno o pravu protivne stranke da traži njihovu naknadu, vrijedilo bi, mutatis mutandis, i za umješače. ${ }^{23}$

Ono što je rečeno o naknadi troškova u slučaju nedopuštenog odnosno neosnovanog traženja izuzeća suca na odgovarajući bi se način primjenjivalo i u slučaju takvog traženja izuzeća sudskog savjetnika i zapisničara (arg. ex 76.) te vještaka (arg. ex 254.).

\section{SEPARATNO ODLUČIVANJE O NAKNADI TROŠKOVA UZROKOVANIH PODNOŠENJEM PRIJEDLOGA ZA POVRAT U PRIJAŠNJE STANJE}

Prije Novele 2003. u Zakonu nije bilo posebnih pravila o naknadi troškova incidentalnog postupka iniciranog prijedlogom za povrat u prijašnje stanje. Prema tom uređenju protivna je stranka imala pravo tražiti naknadu troškova od stranke koja je zatražila povrat u prijašnje stanje zbog propuštanja izazvanog slučajem koji joj se dogodio (156/1.), jer je slučaj, svakako, imao značenje opravdanog razloga zbog kojeg se povrat mogao tražiti (117.).

Novelom 2003. unesene su u ZPP odredbe kojima je izričito uređeno pitanje naknade troškova uzrokovanih podnošenjem restitucijskog prijedloga. Prema važećem uređenju, stranka koja traži povrat u prijašnje stanje dužna je protivnoj stranci na njen zahtjev nadoknaditi troškove postupka izazvane propuštanjem i odlučivanjem o prijedlogu neovisno o ishodu spora (122.a.1.). O tom zahtjevu sud je dužan odlučiti bez odgode, neovisno o odluci o glavnoj stvari, i to rješenjem protiv kojega posebna žalba nije dopuštena i koje se može ovršiti prije njegove pravomoćnosti (122.a.2.).

Prema navedenoj odredbi čl. 122.a reč. 1. ZPP-a protivna bi stranka imala pravo na naknadu troškova koji bi joj bili izazvani u „glavnom” postupku dopuštenjem povrata u prijašnje stanje. Tako bi, između ostaloga, imala pravo na naknadu troškova

preveniranju prakse zloupotrebe instituta izuzeća, a s druge u povećanju opće ekspeditivnosti i ekonomičnosti parničnoga postupka.

23 V. bilj. 8. Dika, O troškovnom statusu umješača nakon Novele Zakona o parničnom postupku iz 2019. 
ponovljenog ročišta koje bi se održalo zato što je stranka koja je zatražila povrat iz opravdanih razloga propustila prethodno određeno ročište, zbog čega je izgubila pravo na poduzimanje radnji koje je (najkasnije) mogla poduzeti samo na tom ročištu. ${ }^{24}$ Riječ je o odgovornosti za naknadu troškova po načelu presumirane objektivne uzročnosti. Pritom bi se odredba čl. 122.a reč. 1. ZPP-a mogla, polazeći od njezinog doslovnog sadržaja, protumačiti i u smislu da bi stranka koja je zatražila povrat bila uvijek dužna naknaditi troškove koje bi time izazvala - čak i ako bi dokazala da je razlog za propuštanje izazvala protivna stranka, npr. time što ju je spriječila da dođe na ročište. ${ }^{25}$ Takvo bi tumačenje, međutim, dovodilo do rezultata koji bi bio protivan s načelom koje propisuje dužnost savjesnoga korištenja pravima u postupku (9.), da bi, unatoč njihovoj načelnoj zabrani, pristajalo i na zloupotrebe prava u postupku koje sud ne smije dopustiti (10.), da bi bilo protivno Ustavom zajamčenom pravu na pravično suđenje (29/1. URH). Zato bi odredbu čl. 122.a reč. 1. ZPP-a trebalo protumačiti u smislu da bi stranka koja traži povrat bila dužna protivnoj stranci naknaditi troškove postupka izazvane propuštanjem i odlučivanjem o prijedlogu za povrat neovisno o ishodu spora, osim ako se razlog zbog kojega bi se tražio povrat ne bi mogao pripisati krivnji protivne stranke ili slučaju koji se njoj dogodio. Ako bi razlog zbog kojega se traži povrat bio uzrokovan krivnjom protivne stranke ili slučajem koji joj se dogodio, ta bi stranka bila dužna naknaditi troškove koje bi zbog toga pretrpjela stranka koja je zatražila povrat (156.). U tom bi smislu osnovno pravilo koje je mjerodavno za naknadu posebnih troškova izazvanih prijedlogom za povrat u prijašnje stanje (122.a), utemeljeno na načelu presumirane objektivnoj uzročnosti, bilo korigirano načelima dokazane krivnje ili objektivne uzročnosti (156.).

Odredba čl. 122.a reč. 1. ZPP-a, prema kojoj je stranka koja traži povrat dužna protivnoj stranci naknaditi troškove postupka izazvane: (1.) propuštanjem i (2.) odlučivanjem o prijedlogu za povrat neovisno o ishodu spora, nameće potrebu da se odvojeno odrede troškovi svake od tih dviju naznačenih radnji. Troškovi izazvani propuštanjem bili bi, npr. troškovi koje je protivna stranka imala u vezi s radnjama koje bi izgubile svoju relevantnost zato što bi povrat bio odobren ( $\arg$. ex 117/3.), npr. troškovi ročišta na koje je protivna stranka bila pristupila, a koja je stranka koja traži povrat propustila. Tu bi spadali i dopunski troškovi izazvani poduzimanjem dodatnih radnji nakon odobrenja povrata koji protivna stranka ne bi imala da nije došlo do propuštanja. Troškovi koji bi bili izazvani odlučivanjem o prijedlogu za povrat bili bi zapravo troškovi incidentalnog postupka iniciranog podnošenjem prijedloga za povrat, npr. troškovi eventualnoga posebnog očitovanja protivne stranke o tom prijedlogu,

24 U tom bi smislu stranka koja je propustila upustiti se u raspravljanje o glavnoj stvari na pripremnom ročištu, ako joj tužba prethodno nije bila dostavljena radi davanja pisanog odgovora (284/2., 288.a/4.), bila ovlaštena zatražiti povrat u prijašnje stanje ako bi iz opravdanih razloga propustila to ročište i zbog toga propustila pravodobno istaknuti prigovor stvarne (17/1.) ili mjesne (20/1.) nenadležnosti. Ta bi stranka bila dužna protivnoj stranci, na njezin zahtjev, naknaditi, neovisno o ishodu spora u glavnoj stvari, troškove toga ponovljenog ročišta.

25 Takve su situacije, npr. zamislive u bračnim sporovima u kojima bi jedan od supružnika fizički onemogućio drugom da dođe u sud. Zamisliva je i situacija u kojoj odvjetnik jedne od stranaka ne bi došao na ročište zato što ga je odvjetnik protivne stranke obavijestio da je sudac bolestan i da je ročište odgođeno. 
troškovi ročišta određenog u povodu prijedloga (121/2.); to bi bili i troškovi koji bi nastali u povodu zahtjeva za naknadu troškova izazvanih prijedlogom za povrat.

Navedenu odredbu čl. 122.a reč. 1. ZPP-a bilo bi inače moguće (barem) dvojako protumačiti. Prvo, u smislu da bi stranka koja traži povrat bila dužna protivnoj stranci naknaditi i troškove izazvane ,propuštanjem i odlučivanjem o prijedlogu za povrat” neovisno o tome bi li on bio odobren ili ne, što znači da bi protivna stranka imala pravo na naknadu troškova toga postupka i kad bi povrat bio dopušten, iako mu se ona protivila. Drugo, u smislu da bi protivna stranka imala pravo na naknadu troškova koji bi joj bili uzrokovani „propuštanjem i odlučivanjem o prijedlogu” samo ako bi u njemu ,uspjela”, ako bi sud, dakle, odbacio ili odbio prijedlog za povrat, odnosno, ako bi prijedlog bio prihvaćen, ako ne bi dala povod za „propuštanje i odlučivanje o prijedlogu". Čini se da bi općim zasadama parničnog troškovnog materijalnog prava (154., 156., 157., 158.) više odgovaralo drugo navedeno tumačenje. Naime, nedovoljno precizno stipuliranu odredbu čl. 122.a reč. 1. ZPP-a trebalo bi uskladiti s tim zasadama. Zbog toga stranci koja bi se neopravdano opirala prijedlogu za povrat koji bi bio prihvaćen, ne bi trebalo priznati pravo na naknadu onih troškova izazvanih „,propuštanjem i odlučivanjem o tom prijedlogu” za koje bi se dokazalo da je povod za njihov nastanak svojim ponašanjem dala ta stranka (arg. ex 157.). ${ }^{26}$ Štoviše, ona bi (prema načelu dokaznog davanja povoda za vođenje postupka /arg. ex 157., 158/2. ${ }^{27 /}$, koje bi, arg. a maiori ad minus, uključivalo i dokazano davanje povoda za poduzimanje određenih radnji) trebala biti osuđena da stranci koja je povrat zatražila naknadi troškove koje bi joj dodatno bili izazvani njezinim neopravdanim protivljenjem. Protivnoj bi stranci ako bi prijedlog za povrat bio prihvaćen, dakle, trebalo priznati pravo na naknadu troškova koji bi joj bili uzrokovani ,propuštenjem i odlučivanjem o prijedlogu za povrat" - ako se ne bi dokazalo da je dala povod za podnošenje toga prijedloga $\mathrm{i}$ ako bi, prije nego što bi se u povodu njega upustila u raspravljanje, priznala njegovu osnovanost (arg. per analogiam ex 157.). Njoj bi trebalo priznati pravo na naknadu troškova i ako bi odluku prepustila sudu. Njoj bi, zatim, trebalo priznati to pravo i ako bi inzistirala na tome da se opravdanost prijedloga za povrat potkrijepi valjanim dokazima. Sjedne strane, jer bi na stranci koja traži povrat bio teret dokazivanja njegove opravdanosti, a, s druge jer bi trebala snositi troškove izazvane slučajem koji joj se dogodio (156/1.). Odgovornost za naknadu troškova prema odredbi čl. 122.a reč. 1. ZPP-a se zapravo u bitnome svodi na odgovornost za naknadu troškova prema načelu objektivne uzročnosti.

De lege ferenda, valjalo bi razmisliti o tome da se (i) o naknadi troškova incidentalnog postupka iniciranog prijedlogom za povrat u prijašnje stanje odlučuje prema načelu dokazanog opravdanog razloga. To znači da ni stranka koja bi postavila zahtjev za povrat koji bi bio odobren jer bi bilo utvrđeno da za to postoje opravdani razlozi, kao ni stranka koja bi mu se protivila i koja bi imala opravdanih razloga smatrati da je takav njezin stav osnovan - ne bi bile dužne naknaditi troškove protivnoj stranci koje bi joj uzrokovale takvim postupanjem. Uzor za takvo zakonsko rješenje moglo bi se pronaći, kako je to već opetovano rečeno, u odredbi čl. 160. ZPP-a koja 
uređuje naknadu troškova u izlučnim parnicama. ${ }^{28}$

I pri odlučivanju o zahtjevu za naknadu troškova prema odredbi čl. 122.a reč. 1. ZPP-a protivna bi stranka imala pravo na naknadu samo onih troškova koji bi joj nastali u povodu prijedloga za povrat ili općenito u povodu propuštanja koje je dalo povod za njegovo podnošenje koji bi za to bili potrebni ( $\arg$. ex 155.).

Ono što je rečeno o dužnosti stranke da naknadi troškove koji bi prijedlogom za povrat bili uzrokovani protivnoj stranci, odnosno o pravu protivne stranke da traži njihovu naknadu, vrijedilo bi, mutatis mutandis, i za umješače. ${ }^{29}$

\section{SEPARATNO ODLUČIVANJE O NAKNADI TROŠKOVA UZROKOVANIH OMETANJEM DOSTAVE, ODNOSNO NJENIM NEUREDNIM OBAVLJANJEM}

\subsection{Troškovi uzrokovani ometanjem dostave}

Osobu koja neopravdano, u slučajevima predviđenim u glavi 11.ZPP-a („Dostava pismena i razmatranje spisa", 133.-150.), odbije dokazati svoju istovjetnost ili primiti pismeno te osobu koja na neki drugi način ometa dostavu svjesno onemogućavajući ili otežavajući primjenu odredaba te glave sud može novčano kazniti uz odgovarajuću primjenu odredaba čl. 110. ZPP-a (149.a/1.). Stranka kojoj takva osoba opisanim ponašanjem prouzroči dodatne troškove $u$ postupku, može u tom postupku zatražiti od suda da je osudi da joj te troškove naknadi, neovisno o tome je li je novčano kaznio (149.a/2.1.). O tom zahtjevu sud je dužan odlučiti rješenjem bez odgode, neovisno o odluci o glavnoj stvari (149.a/2.2.). Protiv toga rješenja dopuštena je posebna žalba, ali se ovrha na temelju njega može tražiti prije njegove pravomoćnosti (149.a/2.3.).

Navedenim odredbama čl. 149.a ZPP-a utvrđena je odgovornost osoba koje ometaju dostavu za naknadu troškova po jednom posebnom kriteriju - po kriteriju predmnijevanog, odnosno dokazanoga svjesnog onemogućavanja ili otežavanja dostave. Riječ je o jednom posebnom slučaju namjere kao oblika krivnje, koja bi bila osnovom za separatno ostvarivanje naknade troškova neovisno o odluci o naknadi troškova u glavnom postupku.

Postojanje svjesnog onemogućavanja ili otežavanja dostave kao pretpostavke za separatno odlučivanje o naknadi troškova utvrđivalo bi se na dva načina. Uz činjenicu da je u postupku dostave neka osoba odbila dokazati svoju istovjetnost ili primiti pismeno vezala bi se predmnjeva da je svjesno ometala dostavu. U drugim bi slučajevima trebalo dokazati da je ta osoba, ometajući dostavu na neki drugi način, svjesno onemogućavala ili otežavala primjenu odredaba glave 11. ZPP-a. To znači da bi u drugim slučajevima trebalo dokazati određeno ponašanje neke osobe i njenu svijest da takvim ponašanjem ometa dostavu. Pritom bi ponašanje te osobe i u ovim drugim slučajevima trebalo vrednovati uzimajući u obzir predmnjevu o poznavanju prava, što znači da bi se pretpostavljalo postajanje svijesti o kojoj je riječ. Ako bi neka

28 V. bilj. 7. Dika, Naknada troškova u izlučnim parnicama.

29 V. bilj. 8. Dika, O troškovnom statusu umješača nakon Novele Zakona o parničnom postupku iz 2019. 
osoba bila kažnjena zbog svjesnog onemogućavanja ili otežavanja dostave (149.a/1., v. supra), time bi bilo utvrđeno postojanje te pretpostavke i kao osnove za traženje naknade troškova (149.a/2.).

U incidentalnom postupku iz čl. 149.a ZPP-a trebalo bi utvrditi ne samo činjenicu da ih je osoba koja traži naknadu određenih troškova zaista i pretrpjela, već i da je riječ o troškovima koji su bili potrebni za svrhovito vođenje parnice, ali i za svrhovito ostvarivanja prava na traženje njihove naknade (arg. ex 154/2., 155.).

Osoba protiv koje bi bio pokrenut incidentalni postupak za naknadu troškova prema odredbama č. 149.a st. 2. ZPP-a imala bi u tom postupku status incidentalne stranke i njoj bi se u tom postupku moralo omogućiti da se upozna s onim što se protiv nje traži i da se o tome izjasni (arg. ex 5. ZPP-a, 29/1. URH). ${ }^{30}$

Troškovi čija bi se naknada zbog ometanja i otežanja dostave mogla tražiti bili bi, najprije, oni koji bi ometanjem dostave u glavnom postupku bili uzrokovani stranci ili kojem drugom sudioniku u tom postupku, npr. troškovi izazvani odgodom ročišta. U te bi troškove spadali i troškovi incidentalnog postupka za naknadu troškova glavnog postupka iniciranog protiv osobe koja bi ometala dostavu. Ako bi se utvrdila da nije ometala dostavu, ta bi osoba imala pravo tražiti naknadu troškova koji bi joj bili uzrokovani sudjelovanjem u incidentalnom postupku za utvrđivanje njezine odgovornosti u svojstvu incidentalne stranke, npr. uz ostalo, naknadu troškova za odvjetničko zastupanje. ${ }^{31}$

Za postavljanje zahtjeva za naknadu troškova uzrokovanih ometanjem dostave vrijedila bi u načelu opća pravila o tome (164.). Ipak, s obzirom na okolnost da je riječ o odlučivanju o tom zahtjevu trebalo bi omogućiti osobama protiv kojih bi bio istaknut da se o njemu izjasne (v. supra). S obzirom na okolnost trebalo bi da provesti poseban incidentalni postupak radi utvrđivanja pretpostavki za donošenje odluke i, iako to nije izrijekom propisano, trebalo bi glede njegova postavljanja, arg. a cohaerentia, a completudine, per analogiam, primijeniti ono što je izrijekom propisano za postavljanje zahtjeva za naknadu troškova u slučaju neurednog obavljanja dostave (149.b/3., v. infra ad 2.). To bi zahtijevali i razlozi koncentracije u postupanju i procesne ekonomije (arg. ex 10/1.).

30 To znači da se u tom slučaju ne bi smjela doslovno primijeniti odredba čl. 164. st.1. ZPP-a prema kojoj o naknadi troškova sud odlučuje na određeni zahtjev bez raspravljanja. Naime, ta je odredba modelirana prema standardnoj situaciji parnice u kojoj sud već prema stanju spisa može utvrditi relevantne pretpostavke za donošenje svoje odluke o troškovima postupka. U slučaju na koji se odnose odredbe čl. 149.a ZPP-a odluka bi se donosila protiv treće osobe koja bi bila uključena u postupak tek nakon što bi ovlaštena osoba protiv nje istaknula zahtjev za naknadu troškova. Pritom se taj zahtjev ne bi smatrao sporednim zahtjevom kao u slučaju u kojemu se rješava spor između stranaka i koji ima u vidu odredba čl. 164. st. 1. ZPP-a, već o glavnom zahtjevu protiv te treće osobe koja bi tek podnošenjem toga zahtjeva stjecala svojstvo incidentalne stranke. Uz to, pretpostavke o kojima bi ovisila odluka o zahtjevu za naknadu troškova, ako osoba protiv koje bi taj zahtjev bio istaknut ne bila kažnjena zbog ometanja dostave, takve su prirode da ih sud ne bi mogao utvrditi na temelju stanja spisa, i da se radi njihova utvrđivanja mora provesti kontradiktorno raspravljanje.

31 Strankama i drugim sudionicima u postupku trebalo bi priznati pravo da traže i naknadu troškova koji bi im nastali u vezi s njihovim sudjelovanjem u incidentalnom postupku radi kažnjavanja osobe kojoj bi se imputiralo da je sabotirala dostavu. 


\subsection{Troškovi uzrokovani neurednim obavljanjem dostave}

Dostavljača koji nesavjesno obavi koju radnju dostave i zbog toga dođe do znatnijeg odugovlačenja postupka sud može novčano kazniti, primjenjujući odgovarajuće odredbe čl. 110. ZPP-a (149.b/1.). Stranka kojoj je takav dostavljač nesavjesnim obavljanjem svoje dužnosti prouzročio dodatne troškove u postupku, u tom postupku može zatražiti od suda da dostavljača, odnosno pravnu osobu koja za njega odgovara po općim pravilima za naknadu štete osudi da joj te troškove naknadi (149.b/2.1.). ${ }^{32}$

Navedenim odredbama čl. 149.b st. 2. reč. 1. ZPP-a utvrđena je (solidarna - arg. ex 1107/4. ZOO-a) ${ }^{33}$ odgovornost dostavljača (u pravilu poštara) koji obavlja dostavu i pravne osobe koja odgovara za njega (u pravilu pošte), po kriteriju nesavjesnog obavljanja radnje dostave. Ta bi nesavjesnost obuhvaćala namjeru, ali i razne oblike nepažnje.

Savjesnost obavljanja radnje dostave u načelu bi se predmnijevala ako bi pokušaj dostave prima facie bio obavljen u skladu s propisima. To znači da bi protivno sud trebao ex officio utvrditi u incidentalnom postupku kažnjavanja (149.b/1.), odnosno da bi protivno trebala dokazati stranka ili drugi sudionik u postupku koji bi tražio naknadu troškova. Ipak, ako radnje dostave ne bi bile obavljane u skladu s propisima, trebalo bi pretpostaviti da dostava nije savjesno obavljena. Pritom bi trebalo uzeti u obzir i okolnost da se uz dostavnicu veže oboriva predmnjeva o istinitosti njezina sadržaja (arg. ex 149.). Kažnjavanje dostavljača zbog nesavjesnog obavljanja dostave rješavalo bi i pitanje odgovornosti dostavljača pri donošenju odluke o naknadi troškova izazvanih takvim obavljanjem dostave.

Incidentalni postupci kažnjavanja i odlučivanja o zahtjevu za naknadu troškova zbog nesavjesnog obavljanja dostave mogli bi se „spojiti“, ali i odvojeno provesti osobito ako bi se naknada troškova tražila samo protiv pravne osobe koja odgovara za rad dostavljača.

Osoba protiv koje bi bio pokrenut incidentalni postupak za naknadu troškova prema odredbama čl. 149.b st. 2. ZPP-a imala bi u tom postupku status incidentalne stranke. Ako bi taj postupak bio pokrenut protiv dostavljača i pravne osobe koja za njega odgovara po općim pravilima za naknadu štete - oni bi imali status specifičnih suparničara ${ }^{34}$ i svima bi njima u tom postupku trebalo omogućiti da se izjasne o onome što se protiv njih traži (arg. ex 5. ZPP-a, 29/1. URH). ${ }^{35}$

U incidentalnom postupku iz čl. 149.b ZPP-a trebalo bi, uz činjenicu da je dostavljač nesavjesno obavio radnju dostave, utvrditi i činjenicu da su tim obavljanjem

32 Treba uzeti u obzir da, ako bi dostava bila povjerena javnom bilježniku (133.a), da bi odgovarao za neuredno obavljanu dostavu od strane njegova prisjednika ili savjetnika. U tom bi slučaju odredbu čl. 149.b st.1. ZPP-a trebalo primijeniti na odgovarajući način.

33 Zakon o obveznim odnosima, Narodne novine, br. 35/05., 11/08., 125711., 78/15. (dalje: ZOO).

34 Riječ je, zapravo, o materijalnim suparničarima koji bi odgovarali na temelju solidarne zajednice u kojoj bi se nalazili - usp. Mihajlo Dika, Građansko parnično pravo. Knj. 4: Stranke, njihovi zastupnici i treći u parničnom postupku (Zagreb: Narodne novine, 2008.), 134.

35 O neprimjerenosti doslovne primjene odredbe čl. 164. st.1. ZPP-a prema osobama o kojima je riječ vrijedilo bi, mutatis mutandis, ono što je rečeno za primjenu te odredbe u odnosu osobu koja je ometala dostavu - v. supra ad 5.1. 
dostave podnositelju zahtjeva uzrokovani određeni troškovi. Troškovi čija bi se naknada mogla tražiti bili bi, najprije, troškovi koji bi u glavnom postupku bili izazvani stranci ili kojem drugom sudioniku u tom postupku nesavjesnim obavljanjem dostave, npr. troškovi uzrokovani odgodom ročišta. U te bi troškove, zatim, spadali i troškovi incidentalnog postupka za naknadu troškova glavnog postupka iniciranog protiv osoba koje bi odgovarale za nesavjesno obavljanje dostave. Ako bi bilo utvrđeno da nije bilo nesavjesnog obavljanja dostave, osobe protiv kojih bi bio iniciran takav incidentalni postupak imale bi pravo tražiti naknadu troškova koji bi im bili uzrokovani sudjelovanjem u tom postupku, npr. naknadu troškova za odvjetničko zastupanje.

Opće pravilo da se naknađuju samo potrebni troškovi (155.) primjenjivalo bi se i pri odlučivanju o zahtjevu za naknadu troškova izazvanih neurednim obavljanjem dostave.

Zahtjev za naknadu troškova uzrokovanih nesavjesnim obavljanjem dostave stranka (i drugi sudionici u postupku) mogu postaviti u roku od petnaest dana od saznanja za razloge koji opravdavaju njegovo postavljanje, a najkasnije do pravomoćnosti, odnosno završetka postupka u povodu izvanrednog pravnog lijeka (149.b/3.). Bila bi riječ o prekluzivnom roku, zbog čijeg bi se propuštanja mogao tražiti povrat u prijašnje stanje (117.). Iako to nije izrijekom predviđeno, taj bi se zahtjev mogao postaviti pred prvostupanjskim sudom neovisno o tome u kojem bi se stadiju postupak nalazio. On bi se, međutim, mogao istaknuti i u postupku pred sudom višeg stupnja ako bi dodatni troškovi bili izazvani nesavjesnim obavljanjem dostave u postupku pred tim sudom, u kojem bi slučaju taj sud proslijedio taj zahtjev prvostupanjskom sudu radi odlučivanja. Na prihvaćanje takvog rješenja upućivale bi, per analogiam, arg. a cohaerentia, odredbe po kojima postupak kažnjavanja sudionika u postupku koji teže zloupotrebe svoja postupovna prava provodi prvostupanjski sud, eventualno na inicijativu suda višeg stupnja (10/4., 5.; 110.; 318.).

O zahtjevu za naknadu troškova uzrokovanih neurednom dostavom, sud je dužan, neovisno o odluci o glavnoj svari, odlučiti bez odgode rješenjem (149.b/2.2.), protiv kojega je dopuštena (samostalna) žalba, kojim bi se, međutim, unatoč mogućnosti ulaganja takve žalbe, ovrha mogla tražiti i prije njegove pravomoćnosti (149.b/2.3.).

\section{NAKNADA TROŠKOVA UZROKOVANIH NEPRAVODOBNIM IZNOŠENJEM NOVIH ČINJENICA I PREDLAGANJEM NOVIH DOKAZA TE NEPRAVODOBNIM PODNOŠENJEM PODNESAKA}

\subsection{Dužnost naknade troškova uzrokovanih nepravodobnim iznošenjem novina tijekom glavne rasprave}

Stranke su dužne već u tužbi i odgovoru na tužbu, a najkasnije na pripremnom ročištu iznijeti sve činjenice na kojima temelje svoje zahtjeve, predložiti dokaze potrebne za utvrđivanje iznesenih činjenica te se izjasniti o činjeničnim navodima i dokaznim prijedlozima protivne stranke (299/1.). ${ }^{36}$ Stranke, ipak, mogu i tijekom

36 Bydlinski, Kommentar zu den Zivilprozessgesetzen, 702, ističe da bi skrivljeno zakašnjelo 
glavne rasprave iznositi nove činjenice i predlagati nove dokaze, ali samo ako ih bez svoje krivnje nisu mogle iznijeti, odnosno predložiti prije zaključenja prethodnog postupka (299/2.). ${ }^{37}$ U Zakonu više nema odredbe kojom je bilo izrijekom riješeno pitanje snošenje troškova izazvanih iznošenjem novih činjenica i predlaganjem novih dokaza tek u stadiju glavne rasprave (299/2.1. ZPP 2003). ${ }^{38}$ Riječ je o pitanju na

iznošenje činjeničnih navoda i dokaznih prijedloga jedne od stranaka kojim bi njezinu protivniku bili uzrokovani troškovi, bilo prema $\S 48$. st. 1. öZPO-a prvo, tzv. separacijsko činjenično stanje. Pritom bi se u pravilu iz samog zakašnjenja izvodio zaključak o krivnji, unatoč tome što bi se, doslovno prema zakonu, trebalo raditi o skrivljenom zakašnjenju, objašnjavajući to i time da se proceduralnim sredstvima koja stoje na raspolaganju radi utvrđivanja osnovanosti zahtjeva za naknadu troškova teško može ispitati postoji li „subjektivno prigovorljivo držanje“.

37 Iz odredbe čl. 299. st.2. ZPP-a proizlazi da bi teret dokazivanja okolnosti da stranka bez svoje krivnje nije iznijela nove činjenice i predložila nove dokaze prije zaključenja prethodnog postupka bio na stranci koja bi to učinila. Ako ona tu okolnost ne bi uspjela dokazati na razini sigurnosti, trebalo bi uzeti da je skrivljeno propustila iznijeti nove činjenice i predložiti nove dokaze (arg. ex 221.a). Bila bi riječ o jednom posebnom slučaju dokazivanja, tzv. negativne činjenice - nekrivnje. Stranka bi mogla dokazati da nije kriva zbog zakašnjelog iznošenja novih činjenica i predlaganju novih dokaza ako bi, npr. dokazala da je do toga došlo zbog slučaja koji joj se dogodio, odnosno zbog (isključive) krivnje protivne stranke ili slučaja koji se njoj dogodio. Ona bi mogla isključiti svoju krivnju i ako bi dokazala da se razlog zbog koga je došlo do potrebe za iznošenjem novota može pripisati sudu ili trećoj osobi bez njene skrivljene participacije u tome.

38 Prema uređenju parničnog postupka koje je vrijedilo nakon Novele 2003. do Novele 2013. stranke su bile dužne već u tužbi i odgovoru na tužbu, na pripremnom ročištu ili najkasnije na prvom ročištu za glavnu raspravu ako pripremno ročište nije održano iznijeti sve činjenice na kojima su temeljile svoje zahtjeve, predložiti dokaze potrebne za utvrđivanje iznijetih činjenica te se izjasniti o činjeničnim navodima i dokaznim prijedlozima protivne stranke (prij. 299/1.). Stranke su, međutim, mogle i kasnije tijekom glavne rasprave iznositi nove činjenice i predlagati nove dokaze, ali su bile dužne naknaditi troškove koji bi time bili izazvani protivnoj stranci, osim ako potreba za iznošenjem novih činjenica i predlaganja novih dokaza nije bila izazvana ponašanjem protivne stranke (prij. 299/2.1.). Na zahtjev protivne stranke, sud je bio dužan bez odgode rješenjem odlučiti o naknadi takvih troškova rješenjem (prij. 299/2.2.) protiv kojega posebna žalba nije bila dopuštena, rješenjem na temelju kojega se ovrha mogla tražiti prije njegove pravomoćnosti (prij. 299/2.3.). Stranke su mogle i između ročišta za glavnu raspravu upućivati podneske i u njima iznositi nove činjenice i predlagati nove dokaze (prij. 299/3.1.), s time da su se i u tim slučajevima odredbe st. 2. čl. 299. ZPP 2003. primjenjivale na odgovarajući način (prij. 299/3.2.).

Prema supra navedenoj odredbi st. 2. reč. 1. čl. 299. ZPP 2003., stranka koja bi tek tijekom glavne rasprave iznijela nove činjenice i predložila nove dokaze bila je ovlaštena to učiniti, ali je u pravilu bila dužna naknaditi protivnoj stranci troškove koji bi joj time bili izazvani, osim ako potreba za iznošenjem novih činjenica i predlaganja novih dokaza nije bila izazvana ponašanjem protivne stranke. Tim je zakonskim rješenjem u parnično troškovno materijalno pravo uneseno pravilo o naknadi posebnih troškova postupka koji bi mogli biti izazvani iznošenjem novih činjenica i predlaganjem novih dokaza u stadiju glavne rasprave po načelu presumirane objektivne uzročnosti. Naime, uz činjenicu da bi neke nove činjenice bile iznesene, odnosno novi dokazi predloženi tek u stadiju glavne rasprave kao presumptivnu bazu vezala se predmnjeva o odgovornosti za naknadu troškova koji bi time bili izazvani protivnoj stranci. Ipak, primjena toga načela bila je korigirana mogućnosti da stranka koja bi tek tijekom stadija glavne rasprave iznijela određene novine bude oslobođena obveze naknade troškova protivnoj stranci, ako bi dokazala da je potreba za njihovim iznošenjem bila izazvana ponašanjem 
koje bi de lege lata, polazeći od načina na koji je stipulirana odredba čl. 299. st. 2. ZPP-a 2013, bilo moguće odgovoriti prihvaćanjem (barem) jedne od sljedećih dviju interpretativnih mogućnosti.

Prema jednoj od njih, stranka koja bi bez svoje krivnje iznijela nove činjenice odnosno predložila nove dokaze tek u stadiju glavne rasprave bila bi ovlaštena to učiniti, ali bi bila dužna protivnoj stranci naknaditi troškove koji bi joj bili uzrokovani takvim iznošenjem novina, ako bi ono bilo posljedica slučaja koji joj se dogodio (156/1.). To znači da ona ne bi bila dužna naknaditi te troškove protivnoj stranci ako bi se odgovornost za naknadno iznošenje novina mogla pripisati protivnoj stranci, njenom umješaču ili nekoj trećoj osobi, odnosno ako bi bila izazvana oficijelnom radnjom suda - u tim se slučajevima ne bi radilo o slučaju koji se njoj dogodio. Ona bi, štoviše, u slučajevima u kojima bi se odgovornost za naknadno iznošenje novina mogla pripisati protivnoj stranci ili nekoj drugoj osobi bila ovlaštena od njih tražiti naknadu dodatnih troškova koji bi joj uslijed toga nastali.

Prema drugoj interpretativnoj mogućnosti, stranka koja bi dokazala da nije kriva što tek u stadiju glavne rasprave iznosi nove činjenice i predlaže nove dokaze, dokazala bi time da njezino pravo na iznošenje novina nije prekludirano i da stoga može tu radnju poduzeti bez ikakvih štetnih posljedica - isto kao tijekom prethodnog postupka (299/1.). Ona ne bi bila dužna naknaditi troškove protivnoj stranci čak i ako bi do naknadnog iznošenja novina došlo zbog slučaja koji joj se dogodio (156/1.). Po tome bi se ova situacija razlikovala od situacije u kojoj bi se mogao tražiti povrat u prijašnje stanje. Traženje povrata pretpostavlja prekluziju, gubitak prava na poduzimanje radnje zbog propuštanja roka ili ročišta (117.). U slučaju iz čl. 299. st. 2. ZPP-a do prekluzije prava na iznošenje novota ne bi došlo ako bi stranka dokazala da bez svoje krivnje nije prije iznijela nove činjenice i/ili predložila nove dokaze, zbog čega bi se smatralo da je to učinila pravodobno. Zato bi se u tom slučaju na naknadu troškova koji bi bili izazvani iznošenjem novota tek u stadiju glavne rasprave primjenjivala opća pravila o konačnom snošenju troškova postupka. To znači da bi stranka koja bi bez svoje krivnje tek u stadiju glavne rasprave iznijela nove činjenice i/ili predložila nove dokaze imala pravo tražiti naknadu troškova izazvanih naknadnim poduzimanjem tih radnji po pravilima koja bi in concreto bila mjerodavna za konačno snošenje troškova postupka (154., 157., 158., 160.). Ona bi po tim pravilima odgovarala i protivnoj stranci za troškove koje bi joj naknadnim iznošenjem novina uzrokovala. I po ovoj bi interpretativnoj mogućnosti stranka, koja bi dokazala da nije kriva za to što je određene nove činjenice iznijela i/ili dokaze predložila tek tijekom stadija glavne rasprave, mogla tražiti od protivne stranke i/ili njezina umješača naknadu dodatnih troškova ako bi naknadno iznošenje novina bilo uzrokovano njihovom krivnjom ili slučajem koji im se dogodio (156.).

Ako se usporede navedene dvije interpretativne mogućnosti, čini se da bi načinu na koji je zakonski uređeno pravo na iznošenje novina tijekom parničnog postupka,

protivne stranke (prij. 299/2.), bila je korigirana mogućnosti dokaza o protivnom utemeljenom na načelu dokazane uzročnosti. U tom je slučaju ona, štoviše, u pravilu mogla tražiti od protivne stranke naknadu troškova koji bi joj bili uzrokovani takvim njenim ponašanjem - po načelu dokazne krivnje ili dokazane objektivne uzročnosti (156/1.). 
a posebno u stadiju glavne rasprave, više odgovarala druga izložena mogućnost, posebno stoga što bi se njome ublažile posljedice pretjeranog ograničenja toga prava tijekom prvostupanjskog postupka. Prihvaćanjem takvog tumačenja odredbe čl. 299. st. 2. ZPP-a, uvela bi se kvalitativna razlika između pretpostavki kojima je uvjetovana dopuštenost naknadnog iznošenja novina tijekom glavne rasprave $\mathrm{i}$ instituta povrata $\mathrm{u}$ prijašnje stanje (v. supra ad 4.).

Prema obje interpretativne varijante, ako bi stranci određeni dodatni troškovi bili uzrokovani radnjom suda, pravo na njihovu naknadu ovisilo bi o pravilima koja bi in concreto bila mjerodavna za konačno snošenje troškova postupka, osim ako koja od stranaka ne bi skrivljeno navela sud na donošenje takve odluke (v. 2.).

Stranka koja ne bi uspjela dokazati da bez svoje krivnje nije pravodobno iznijela nove činjenice i predložila nove dokaze, zbog čega bi došlo do prekluzije njenog prava na poduzimanje tih radnji, mogla bi tražiti povrat u prijašnje stanje ako bi uspjela dokazati da, unatoč tome što je skrivljeno to propustila pravodobno učiniti, postoje drugi razlozi koji bi to opravdavali, što bi zapravo bilo vrlo teško. Ako bi, ipak, u tome uspjela, za donošenje odluke o naknadi troškova postupka bila bi mjerodavna odredba čl. 122.a reč. 1. ZPP-a (v. supra 2.).

\subsection{Dužnost naknade troškova uzrokovanih nepravodobnim podnošenjem podnesaka tijekom prvostupanjskog postupka}

Tijekom prvostupanjskog postupka sud može pozvati stranke da se u roku koji, u pravilu, neće biti duži od 30 dana pisano očituju na navode protivne stranke (299.a/1.), ${ }^{39}$ uz upozorenje na posljedice zakašnjenja (299.a/4.). „Stranka se može na navode protivne stranke pravodobno očitovati i bez poziva suda tako da njezin podnesak bude dostavljen sudu i protivnoj strani najkasnije osam dana prije sljedećeg

39 Navedena odredba čl. 299.a st. 1. ZPP-a odnosi se izravno na stadij glavne rasprave. Takav bi zaključak proizlazio iz okolnosti da se ona nalazi u glavi 21. ZPP-a „Glavna rasprava”, ali i iz okolnosti da se u st. 2. čl. 299.a ZPP-a izrijekom navode pripremno ročište i ročište za glavnu raspravu, iz koje bi se odredbe moglo izvesti da bi zakonodavac, da je htio da se odredba st. 1. čl. 299.a ZPP-a odnosi i na pisana očitovanja koja se podnose tijekom prethodnog postupka, to svakako i rekao. Čini se, međutim, da bi bilo smislenije odredbu o kojoj je riječ protumačiti u smislu da se ona općenito odnosi na prvostupanjski postupak, dakle i na prethodni postupak i na stadij glavne rasprave. Tome bi u prilog govorila, arg. a cohaerentia, a completudine, odredba st. 2. toga članka koja se izrijekom referira i na prethodni postupak, ali i odredba čl. 288. st. 4. ZPP-a, prema kojoj na pripremnom ročištu sud ima u pogledu upravljanja postupkom sva ovlaštenja koja ima na ročištu za glavnu raspravu, odredba koja bi se odnosila i na rokove koje bi sud određivao u tom stadiju postupka. Svoje uporište takvo bi tumačenje moglo pronaći i u odredbi čl. 155. st. 1. ZPP-a prema kojoj sud svoju ocjenu o potrebnosti nekih troškova donosi, uz ostalo, vodeći računa o pravilima ZPP-a koja za pripremanje glavne rasprave određuju upućivanje podnesaka i jedno pripremno ročište te jedno ročište za glavnu rasprave, dakle, upućuju na odredbe čl. 284. do 292. ZPP-a u kojima se izrijekom spominju samo tužbu i odgovor na tužbu te pripremno ročište. Konačno, takvo bi tumačenje bilo u skladu is odredbama o dužnostima stranaka da se savjesno koriste svojim procesnim ovlaštenjima (9.) te da nastoje da se postupak provede bez odugovlačenja, u razumnom roku, i sa što manje troškova (10/1.), odredbama koja se općenito odnose na cijeli parnični postupak. De lege ferenda, valjalo bi izrijekom domašaj svih odredaba čl. 299.a ZPP-a protegnuti i na prethodni postupak. 
pripremnog ročišta ili ročišta za glavnu raspravu" (299.a/2.). Podneske koji su predani protivno navedenim odredbama (299.a/1., 299.a/2.) ,sud neće uzeti u obzir" (299.a/3.1.). „Iznimno, stranka može tražiti da ih sud uzme u obzir ako ih bez svoje krivnje nije mogla podnijeti pravodobno ili ako njihovo uzimanje u obzir ne bi dovelo do odugovlačenja postupka" (299.a/3.2.).

Iz navedenih odredbi čl. 299.a ZPP-a proizlazilo bi da bi stranku pogađala specifična uvjetna prekluzija prava na podnošenje podnesaka kojima bi se očitovala o navodima protivne stranke ako to ne bi učinila u roku koji bi joj sud odredio (299.a/1.), odnosno, ako sud za to ne bi odredio rok, ako to ne bi učinila barem osam dana prije sljedećeg pripremnog ročišta ili ročišta za glavnu raspravu (299.a/2.). Ta bi se prekluzija očitovala u tome što podneske koji ne bi bili pravodobno podneseni sud ne bi smio uzeti u obzir, što bi ih morao tretirati kao da nisu ni podneseni. Riječ je o uvjetnoj prekluziji zato što bi njezino nastupanje ovisilo o tome hoće li stranka uspjeti dokazati da nije kriva za to što podneske nije pravodobno podnijela, odnosno dokazati da njihovo uzimanje u obzir - neovisno o krivnji stranke - ne bi dovelo do (treba uzeti, bitnog) odugovlačenja postupka.

U usporedbi s odredbom čl. 299. st. 2. ZPP-a (v. supra ad 6.1.) razlike u posljedicama nepostupanja u skladu s odredbama čl. 299.a st. 1. i 2. ZPP-a bile bi u tome što bi sud mogao, neovisno o krivnji stranke, uvažiti i podneske koji nisu pravodobno podneseni ako se njihovim uzimanjem u obzir ne bi (bitno) odugovlačio postupak, što bi, između ostaloga, moglo ovisiti i o njegovoj ocjeni do koje su mjere oni relevantni za pravilnost i zakonitost suđenja.

Kad je riječ o pravu stranke da traži naknadu troškova koji bi joj bili uzrokovani nepravodobnim podnošenjem podnesaka od strane protivne stranke prema odredbama čl. 299.a ZPP-a, bilo bi moguće na odgovarajući način primijeniti ono što je rečeno $u$ vezi s pravom stranke da traži naknadu dodatnih troškova uzrokovanih nepravodobnim iznošenjem novih činjenica i predlaganjem novih dokaza tijekom stadija glavne rasprave (v. supra ad 6.1.). To bi značilo da bi stranka prema načelu presumirane objektivne uzročnosti u pravilu bila dužna protivnoj stranci naknaditi troškove koje bi joj uzrokovala nepravodobnim podnošenjem podnesaka ako bi sud našao da ih ne treba uzeti u obzir. Kad je, međutim, riječ o naknadi troškova uzrokovanih nepravodobnim podnošenjem podnesaka u slučaju u kojemu bi se oni ipak uzeli u obzir zato što bi stranka dokazala da nije kriva što je do toga došlo ili da to nije dovelo do odugovlačenja postupka, analogno bi se također otvarale dvije interpretativne mogućnosti kao i kad bi protivna stranka dokazala da bez svoje krivnje nije pravodobno iznijela određene novine (v. supra ad 6.1.).

\section{ZAKLJUČNE NAPOMENE}

Šest procesnih situacija, u kojima je posebnim odredbama ZPP-a uređena mogućnost traženja separatne naknade troškova uzrokovanih jednoj od stranaka tijekom postupka radnjama protivne stranke koje se mogu pripisati njenoj krivnji ili slučaju koji joj se dogodio, svakako uz uvjet da je akuratna, pokazuje, s jedne strane, do kakvih bi različitih tumačenja u praksi (i doktrini) mogla dovesti nedovoljna 
određenost (pa i domišljenost) tih odredaba. S druge strane, indicira i moguće intervencije kojima bi se ne samo otklonile neželjene posljedice koje bi mogla izazvati njihova važeća redakcija, već i unaprijedilo uređenje instituta na koje se odnose. Neke bi od tih intervencija svakako zahtijevale da se prethodno stabiliziraju pravnopolitičke premise od kojih bi trebalo polaziti pri uređenju instituta u vezi s kojima su te odredbe statuirane. To se, po mišljenju autora ovog ogleda, u prvom redu tiče instituta izuzeća i odgovornosti za troškove protivnoj stranci po načelu objektivne uzročnosti u slučaju odbijanja zahtjeva za izuzeće, zapravo potrebe da se kriteriji te odgovornosti dovedu u skladu s Ustavom zajamčenim pravom na nepristrano suđenje.

\section{LITERATURA}

1. Betetto, Nina. U: Pravdni postopek: Zakon s komentarjem, 2. knjiga, ur. Lojze Ude et al. Ljubljana: Uradni list Republike Slovenije: GV založba, 2006.

2. Bydlinski, Michael. U: Kommentar zu den Zivilprozessgesetzen 2. Band / 1. Teilband EGZPO, §§ 1 bis 73 ZPO, Hans Walter Fasching, Andreas Konecny. Wien: Manz, 2002.

3. Dika, Mihajlo. Građansko parnično pravo. Knj. 4: Stranke, njihovi zastupnici i treći u parničnom postupku. Zagreb: Narodne novine, 2008.

4. Dika, Mihajlo. „Naknada troškova u izlučnim parnicama“. Pravo u gospodarstvu 59, br. 3 (2020): 389-411.

5. Dika, Mihajlo. „O konačnom snošenju parničnih troškova prema načelu presumiranog davanja povoda za parnicu nakon Novele ZPP-a 2019. U: Novine u parničnom procesnom pravu: okrugli stol održan 6. prosinca 2019. u palači Akademije u Zagrebu, ur. Jakša Barbić, 17-77. Zagreb: HAZU, 2020.

6. Dika, Mihajlo. „O troškovnom statusu umješača nakon Novele Zakona o parničnom postupku iz 2019.“. U: Zbornik radova s V. međunarodnog savjetovanja „Aktualnosti građanskog procesnog prava nacionalna i usporedna pravnoteorijska i praktična dostignuća“", Split, 17. i 18. listopada 2019. godine, ur. Dinka Šago et al., 1-38. Split: Sveučilište u Splitu, Pravni fakultet, 2019.

7. Presuda Visokog trgovačkog suda Republike Hrvatske Pž-2990/03 od 24.10.2006 INF-N 5664/06.

8. Rechberger, Walter H. i Daphne-Ariane Simotta. Grungriss des österreichischen Zivilprozessrechts, Erkenntnisverfahren. Wien: Manz Verlag, 2017.

9. Ustav Republike Hrvatske, Narodne novine, br. 56/90., 135/97., 8/98., 113/02., 124/00., 28/01., 41/01., 55/01., 76/10., 85/10.

10. Zakon o obveznim odnosima, Narodne novine, br. 35/05., 11/08., 125711., 78/15.

11. Zakon o parničnom postupku, Narodne novine, br. 26/91., 53/91., 91/92., 112/99., 88/01., 117/03., 88/05., 2/07., 96/08., 84/08., 123/08., 57/11., 25/13., 70/19. 


\section{Mihajlo Dika*}

Summary

\section{ON CERTAIN SPECIAL CASES OF ADJUDICATING THE COMPENSATION OF LITIGATION COSTS SEPARATELY}

The paper examines six procedural situations in which special provisions of the Civil Procedure Act regulate the possibility of requesting separate compensation for costs caused to one of the parties during the proceedings by the actions of the opposing party attributable to its guilt/occurrence associated with that party. It is a matter of reimbursement of costs caused by filing an (inadmissible or) unfounded request for disqualification of a judge, filing a motion for reinstatement, obstructing the service and its improper performance, untimely presentation of new facts and proposing new evidence and untimely submission of procedural briefs. After the analysis of the mentioned institutes, an attempt is made to determine their content $d e$ lege lata and to propose legislative corrections (de lege ferenda).

Keywords: costs of the proceedings; exemption of the judge; restitution; service; new facts and evidence.

* Mihajlo Dika, Ph.D., Professor Emeritus, Faculty of Law, University of Zagreb; mihajlo.dika@ pravo.hr. ORCID: https://orcid.org/0000-0002-5659-3779. 